\title{
Electrochemical Impedance Spectroscopy Study of the Mass Transfer in an Anode-Supported Microtubular Solid Oxide Fuel Cell
}

\author{
Hironori Nakajima \\ Kyushu University \\ Japan
}

\section{Introduction}

Solid oxide fuel cell (SOFC) has advantages including high efficiency power generation by operation at $500-1000{ }^{\circ} \mathrm{C}$, which results in a low environmental load. Moreover, SOFCs provide high quality waste heat, and the use of hydrocarbon fuels such as city gas, liquefied petroleum gas, and alcohol is relatively easy. However, for practical use, optimization of the electrode and electrolyte materials and the structure of the cell are required to improve the performance. In addition, optimization of the operation conditions and improvement of cell durability need to be addressed.

Mass transfers of the fuel and oxygen at the anode and cathode, respectively, greatly affect the cell performance by giving rise to the concentration overpotentials which result in the voltage loss of the cell. The concentration overpotentials including the Nernst loss by the fuel and oxygen depletions in the cell (Li, 2007; Morita et al., 2002) also affect the cell durability since they cause current distribution which leads to temperature distribution in the cell and anode oxidation. The current distribution also prevents effective use of whole electrode areas in a cell geometry.

This chapter describes the concentration overpotentials and current distribution in an intermediate temperature anode-supported microtubular SOFC which can be operated in the temperature range of $500-800{ }^{\circ} \mathrm{C}$ (IT-SOFC) with an analysis by electrochemical impedance spectroscopy (EIS) and cell surface temperature measurements.

EIS has been widely employed for the analysis of fuel cells. In particular, the author's group has developed diagnosis methods of operating status of the polymer electrolyte fuel cell (PEFC) by analyzing the variation of resistances and capacitances of equivalent circuit models of the PEFC (Konomi \& Saho, 2006; Nakajima et al., 2008).

For the SOFC, a number of EIS analyses have been reported (Barsoukov \& Macdonald, 2005; Esquirol et al., 2004; Horita et al., 2001; Huang et al., 2007; Ishihara et al., 2000; Jiang, 2002; Leonide et al., 2010; McIntosh et al., 2003). Although many of those reports focused on the characterization of developed materials, there were very few reports (Barfod et al., 2007) that analyze each impedance of the anode and cathode in the full cell impedance of a practical cell simultaneously and separately by applying EIS under operation. 
EIS with two-electrode set-up on the practical microtubular IT-SOFC was thus carried out. To evaluate the impedance variation of each part of the cell under operation, gas feeding conditions for the anode and cathode were varied.

In addition, very few experimental studies on current distributions in a cell that lead to temperature distributions have been reported to date, although a number of computational analyses have been reported (Campanari \& Iora, 2004; Costamagna \& Honegger, 1998; Kanamura \& Takehara, 1993; Nishino et al., 2006; Suzuki et al., 2008). Thus the current distributions are estimated by using the overpotentials evaluated with EIS.

\section{Experimental}

\subsection{EIS measurements}

All measurements were performed using an anode-supported microtubular SOFC(Kawakami et al., 2006) with an outer and an inner diameters of $5 \mathrm{~mm}$ and 3 $\mathrm{mm}$, respectively. The thickness of the electrolyte was $30 \mu \mathrm{m}$ (Ueno, 2005). Anode substrate tube was made of $\mathrm{NiO} /\left(\mathrm{ZrO}_{2}\right)_{0.9}$

$\left(\mathrm{Y}_{2} \mathrm{O}_{3}\right)_{0.1}$ (NiO/YSZ). Anode interlayer of $\mathrm{NiO} /\left(\mathrm{Ce}_{0.9} \mathrm{Gd}_{0.1}\right) \mathrm{O}_{1.95}$ (NiO/GDC10) for low temperature operation was coated onto the anode substrate. Electrolyte was $\mathrm{La}_{0.8} \mathrm{Sr}_{0.2} \mathrm{Ga}_{0.8} \mathrm{Mg}_{0.2} \mathrm{O}_{2.8}$ (LSGM). A layer of $\left(\mathrm{Ce}_{0.6} \mathrm{La}_{0.4}\right) \mathrm{O}_{1.8}$ (LDC40) was inserted between the anode interlayer and electrolyte to prevent undesirable nickel diffusion during cell preparation at high temperature. Cathode made of $\left(\mathrm{La}_{0.6} \mathrm{Sr}_{0.4}\right)\left(\mathrm{Co}_{0.2} \mathrm{Fe}_{0.8}\right) \mathrm{O}_{3}$ (LSCF), whose length in the axial direction was $3.8 \mathrm{~cm}$, was coated on the electrolyte. Geometrical electrode area was $5.9 \mathrm{~cm}^{2}$.

Figure 1 illustrates the configuration of the experimental set-up. Temperature of the quartz tube having an inner diameter of $4.6 \mathrm{~cm}$ was maintained at $700{ }^{\circ} \mathrm{C}$ with an electric furnace. Anode and cathode gas lines were supplied with mixtures of $\mathrm{H}_{2} / \mathrm{N}_{2}$ and $\mathrm{O}_{2} / \mathrm{N}_{2}$ at constant flow rates, respectively. The anode $\mathrm{NiO}$ was reduced to $\mathrm{Ni}$ by feeding $\mathrm{H}_{2} / \mathrm{N}_{2}$ mixture gas for two hours prior to measurements. The anode and cathode were electrically connected with the four-terminal method.

Current-voltage (I-V) curves were measured with a potentio/galvanostat (HA-320, Hokuto Denko Co., Ltd) and mass flow controllers (SEC-40, Horiba STEC) controlled by LabView 8.5 (National Instruments Inc.) on a personal computer through a data acquisition board (NI USB-6008, National Instruments Inc.). ElS measurements were carried out using a frequency response analyzer (FRA) (DS-2100/DS-266/DS-273, Ono Sokki Co Ltd.) combined with the potentio/galvanostat. EIS was carried out with two-electrode set-up without the reference electrode. An equivalent circuit presented in Fig. 2 (Barsoukov \& Macdonald, 2005; McIntosh et al., 2003) is used for the complex nonlinear least square (CNLS) fitting (Barsoukov \& Macdonald, 2005) of obtained impedance spectra with excluding inductive part.

Each resistance and capacitance is evaluated with a CNLS fitting program, Z-View (Scribner Inc.). In this circuit, $R_{\mathrm{hf}}$ and $C_{\mathrm{hf}}$ denote resistance and associated capacitance corresponding to the high frequency arc in the complex-plane plot of the impedance, respectively, $R_{\mathrm{Ohm}}$ is the Ohmic resistance of the cell, $R_{\mathrm{lf}}$ and $C_{\mathrm{lf}}$ are resistance and associated capacitance for the low frequency arc, respectively.

Each one of the R-C branches dominantly represents the charge transfer process in low current density region, and mass transfer process in high current density region. In the 


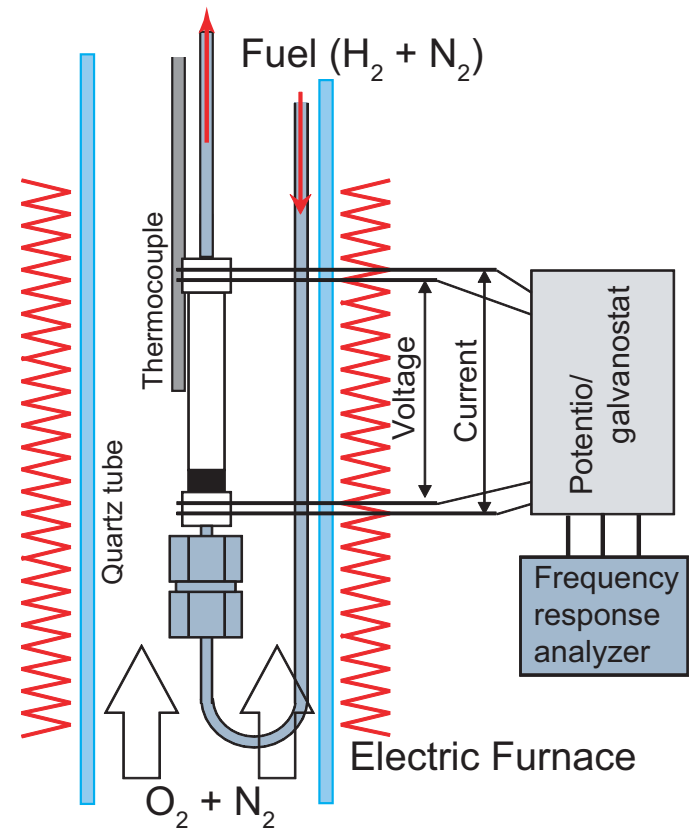

Fig. 1. Experimental set-up of the microtubular SOFC.

present chapter, the equivalent circuit is not separated into the charge and mass transfer processes since the complex plane plots exhibited only two arcs, whose behavior should be analyzed with simple one R-C branch prior to appropriate separations of overlapping arcs and equivalent circuit.

The Nernst loss by the partial pressure gradient of hydrogen and oxygen ascribed to their consumption leads to current distribution in the axial direction. Ohmic resistance in the anode and cathode electrodes is also attributed to this current distribution. However, the author use the above equivalent circuit for uniform current distribution to obtain average behavior over the axial direction of the cell.

As a result, the variations in these circuit parameters are obtained in accordance with current densities, and anode and cathode gas-feed conditions. In addition, the impedance of the mass transfer process can be analyzed as that of the finite length diffusion (Nakajima et al., 2010).

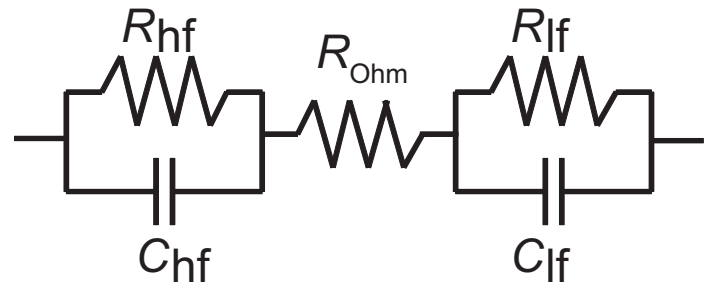

Fig. 2. Equivalent circuit of an SOFC. 


\subsection{Temperature measurements}

During the measurements, anode and cathode were fed upward with mixtures of $\mathrm{H}_{2} / \mathrm{N}_{2}$ and dried air at constant flow rates with current density, respectively. Temperatures at the upper, middle, and lower parts in the axial direction of the anode and cathode surfaces were measured by thermocouples. The cathode side thermocouple tip was fixed with silver paste and wire to retain contact and to minimize radiation heat transfer at the thermocouple with their low emissivity. The changes of the cell voltages by the installation of the thermocouples were less than $3 \%$.

\section{Results and discussion}

\subsection{Evaluation of overpotentials from EIS spectra}

Figure 3 shows the I-V curves for the different anode fed gas flow rates and gas compositions. The performance of this type of the cell significantly depends on the fuel utilization and the partial pressure, indicating the effect of the fuel mass transfer.
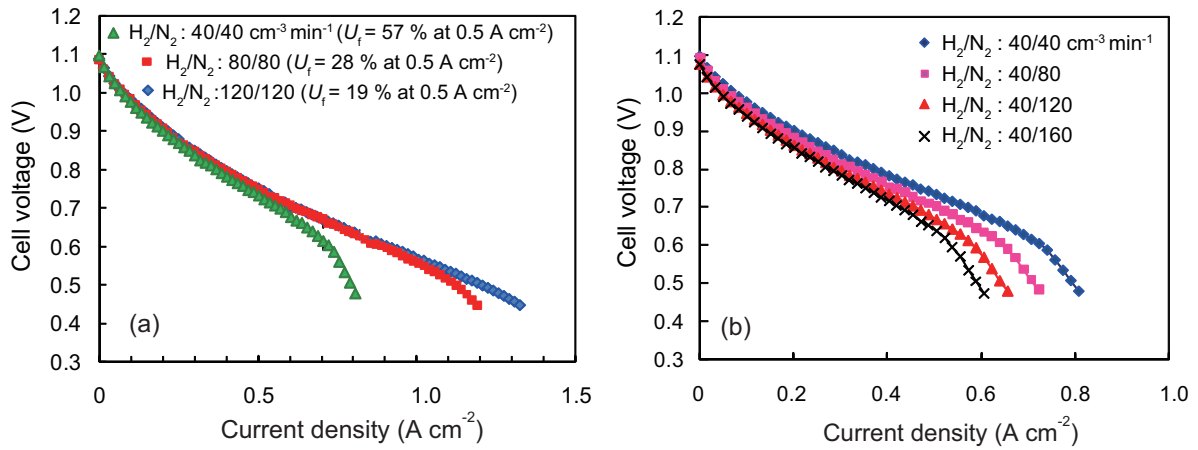

Fig. 3. I-V curves of the SOFC under different (a) anode gas flow rates and (b) partial pressures. Cathode: Dried air of $1000 \mathrm{~cm}^{3} \mathrm{~min}^{-1}$. $U_{\mathrm{ox}}=5.7 \%$ at $0.5 \mathrm{~A} \mathrm{~cm}^{-2}$.

The resistances in the equivalent circuit can be written as the derivatives of the anode, Ohmic, and cathode overpotentials because EIS measures voltage drops in an infinitesimal interval of the current (Konomi \& Saho, 2006; Nakajima et al., 2005). The resistances are non-Ohmic resistance and depend on current density (Nakajima et al., 2006). Overpotentials are hence calculated by integrating each resistance with respect to current as follows.

$$
R_{\mathrm{x}}(I)=\frac{\partial \eta_{\mathrm{x}}}{\partial I}
$$

where $x=h f, O h m$, lf. Each overpotential is then evaluated by integration of those resistances as follows.

$$
\eta_{\mathrm{x}}=\int R_{\mathrm{x}}(I) d I
$$

Figure 4 shows the complex plane plots by EIS, where low frequency arc becomes large according to a decrease in hydrogen partial pressure by variation of the anode gas flow rate from $\mathrm{H}_{2} / \mathrm{N}_{2}=40 / 40 \mathrm{~cm}^{3} \mathrm{~min}^{-1}\left(1 \mathrm{~atm}, 25^{\circ} \mathrm{C}\right.$ ) to $40 / 160 \mathrm{~cm}^{3} \mathrm{~min}^{-1}$. Change of high 
frequency arc is small. In the previous study, the high and low frequency arcs have been found to be attributed to the cathode and anode reactions, respectively, in the low and medium current regions, from the variation of the arcs with anode and cathode gas feeding conditions (Nakajima et al., 2010). Hence anode and cathode impedances can be separated for a cell with two electrode set-up (without the reference electrode) by frequency domain when the time constant (relaxation time) sufficiently differs between the anode and cathode as the present cell.

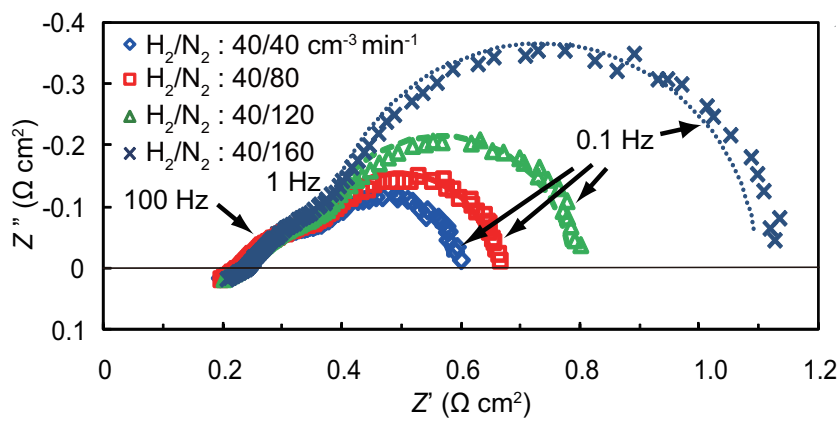

Fig. 4. Complex-plane plots of the SOFC at $0.51 \mathrm{~A} \mathrm{~cm}^{-2}$ under different $\mathrm{H}_{2}$ partial pressures. Cathode: Dried air of $1000 \mathrm{~cm}^{3} \mathrm{~min}^{-1}$. $U_{\mathrm{f}}=58 \%$ and $U_{\mathrm{ox}}=5.8 \%$.

The resistances obtained by the CNLS fitting are numerically integrated according to Eq. 2 . Then overpotential at each part is averagely obtained as illustrated in Fig. 5 with I-V curves. In this case, $\eta_{\mathrm{hf}}$ is the cathode overpotential, $\eta_{\mathrm{c}}, \eta_{\mathrm{Ohm}}$ is the Ohmic overpotential, and $\eta_{\mathrm{lf}}$ is the anode overpotential, $\eta_{\mathrm{a}}$. The I-V curves and voltages evaluated by subtracting the sum of the overpotentials from the open circuit voltage are in good agreement. Each overpotential is presented in Figs. 6 and 7.



Fig. 5. Cell voltage and overpotential map of the SOFC. Cathode: Dried air of 1000 $\mathrm{cm}^{3} \min ^{-1}$. Anode: $\mathrm{H}_{2} / \mathrm{N}_{2}=40 / 40 \mathrm{~cm}^{3} \mathrm{~min}^{-1}$. $U_{\mathrm{f}}=57 \%$ and $U_{\mathrm{ox}}=5.7 \%$ at $0.5 \mathrm{~A} \mathrm{~cm}^{-2}$. 

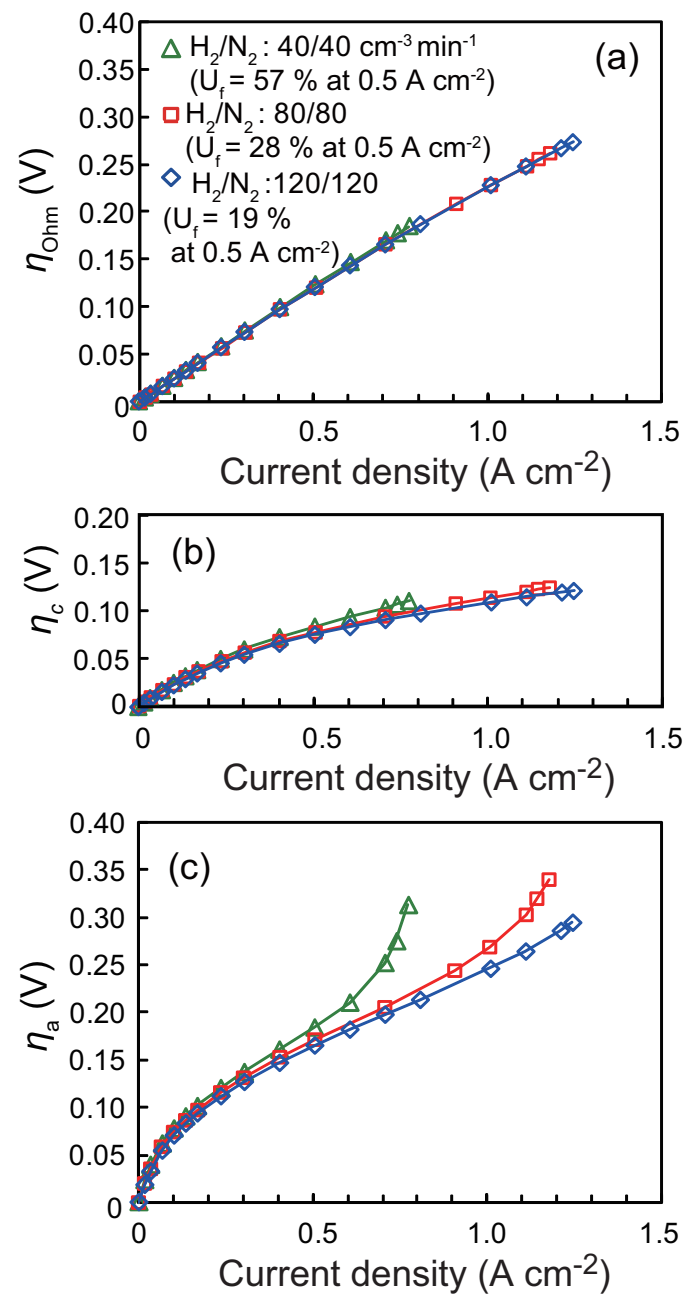

Fig. 6. (a) Ohmic, (b) cathode, and (c) anode overpotentials of the SOFC for different anode gas flow rates. $U_{\mathrm{ox}}=5.7 \%$ at $0.5 \mathrm{~A} \mathrm{~cm}^{-2}$.

\subsection{Anode overpotentials}

The anode and cathode activation overpotentials, $\eta_{\mathrm{aa}}$, and $\eta_{\mathrm{ca}}$, respectively, are then separated using the Butler-Volmer (BV) equation as illustrated in Fig. 8. Thereby the concentration overpotential of the anode, $\eta_{\mathrm{ac}}$, is also separated by subtracting the anode activation overpotentials from the anode overpotentials as presented in Figs. 9 and 10. It should be noted that the overpotential described by the BV type equation is controversial in terms of the electron transfer rate limiting (the activation overpotential) or chemical reaction rate limiting process.

The separation of the overpotentials is successfully confirmed by the observation of the overpotential variation in conjunction with the variation of the anode gas flow rate and 

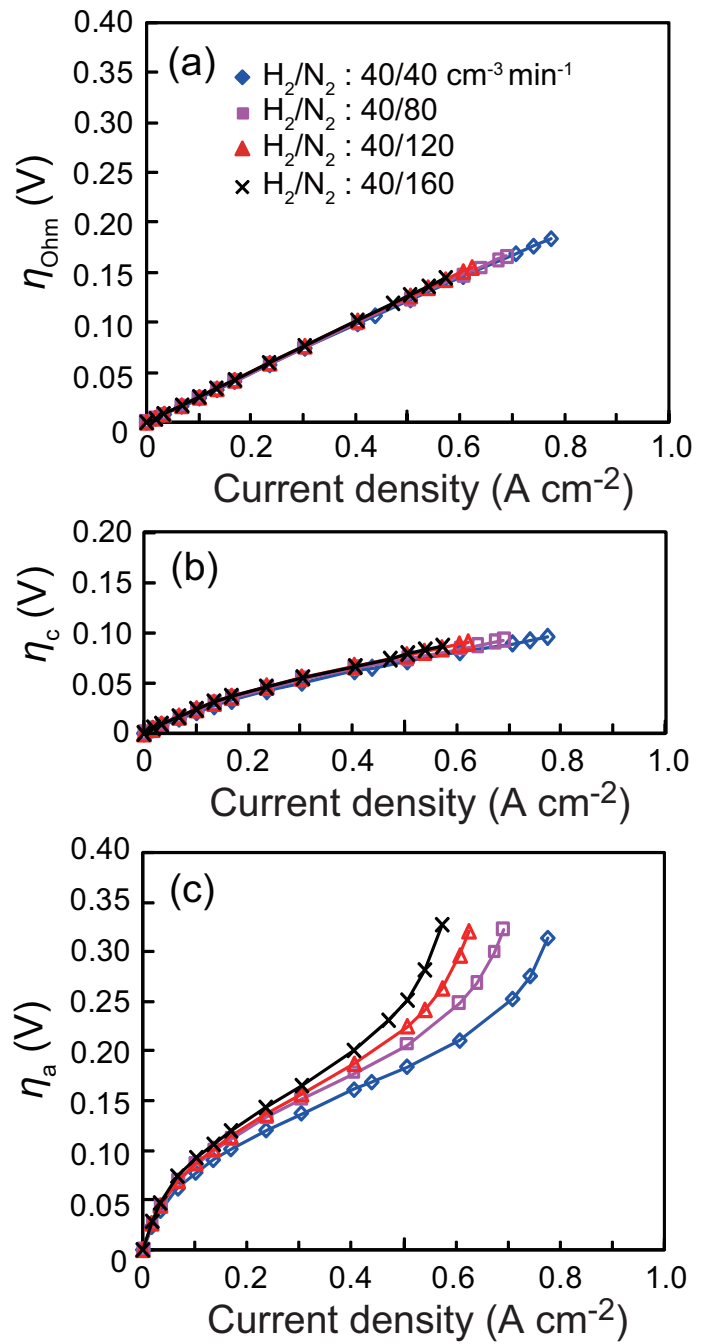

Fig. 7. (a) Ohmic, (b) cathode, and (c) anode overpotentials of the SOFC for different $\mathrm{H}_{2}$ partial pressures. $U_{\mathrm{f}}=57 \%$ and $U_{\mathrm{ox}}=5.7 \%$ at $0.5 \mathrm{~A} \mathrm{~cm}^{-2}$.

composition. When hydrogen partial pressure in the fed gas is decreased, the activation overpotential also increases owing to the decrease in the exchange current density. In this way, EIS can be used to diagnose the cell status under operation.

The Nernst loss due to the fuel partial pressure gradient along the axis by the fuel consumption contributes the large anode concentration overpotential as indicated from the diffusion impedance in the previous report (Nakajima et al., 2010). This Nernst loss results in current distribution along the axis as described in later section. 

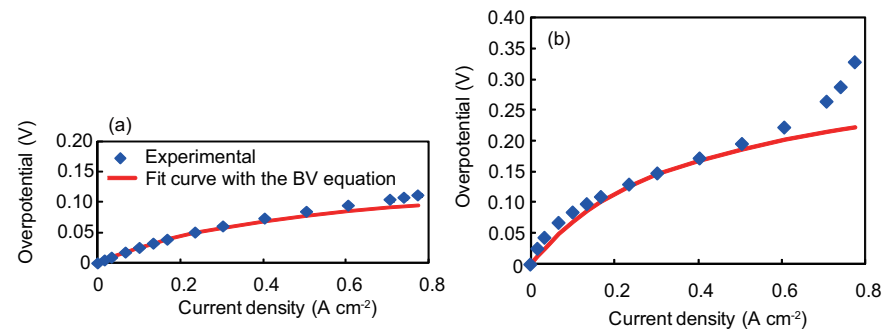

Fig. 8. (a) Activation and (b) concentration overpotentials at the anode of the SOFC for different anode gas flow rates.
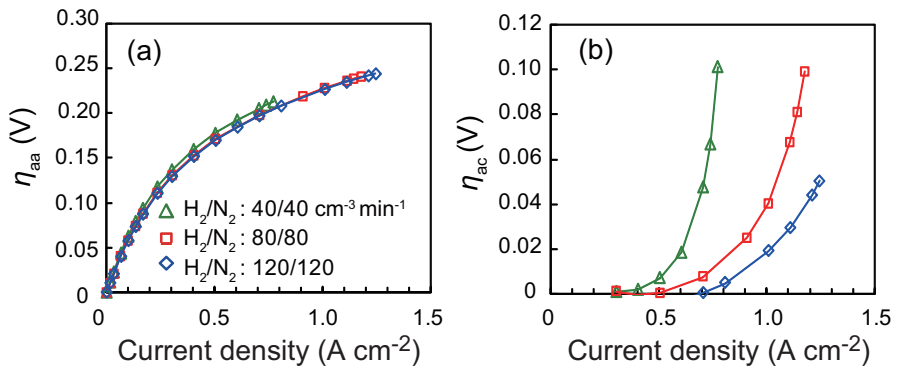

Fig. 9. (a) Activation and (b) concentration overpotentials at the anode of the SOFC for different anode gas flow rates.
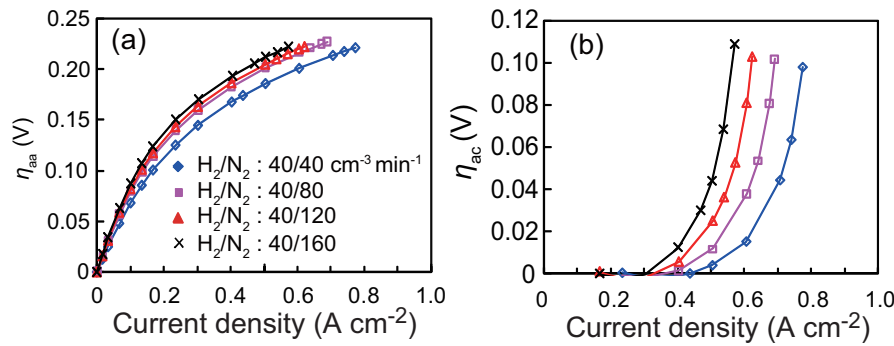

Fig. 10. (a) Activation and (b) concentration overpotentials at the anode of the SOFC for different anode gas flow rates.

\subsection{Cathode overpotentials}

At the cathode, the oxygen utilization was rather smaller than fuel utilization according to practical operation conditions. So, the Nernst loss from the oxygen concentration gradient along the axis is small in contrast to the anode. In the low and medium current regions, the concentration overpotential at the cathode is almost negligible and the activation overpotential is observed as shown in Figs. 6 and 7. However, the large current region in the case of large hydrogen flow rate, decrease in the oxygen partial pressure of the fed gas in the cathode side leads to an increase in the diameter of the low frequency arc of the complex plane plot, that is $R_{\mathrm{lf}}$, as seen in Fig. 11. Thus the oxygen mass transfer impedance is included in the low frequency arc. Hence $\eta_{\text {lf }}$ increases with a decrease in the oxygen partial pressure in the fed gas as shown in Fig. 12(a). 


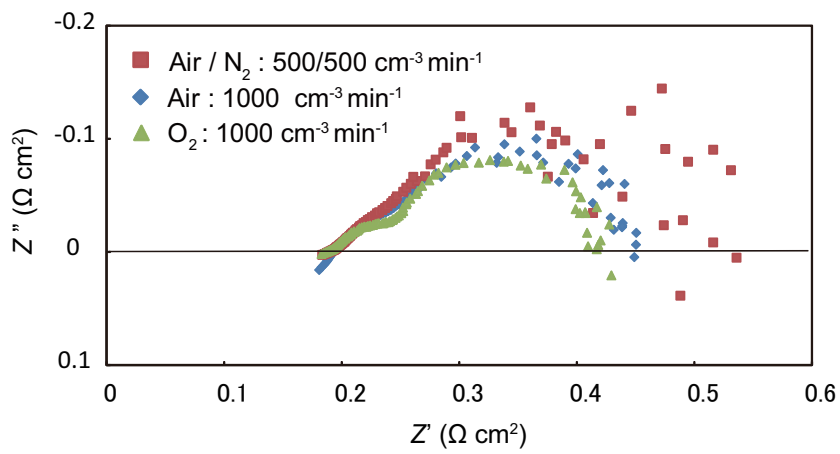

Fig. 11. Complex-plane plots of the SOFC for different oxygen partial pressures.

Assuming that the cathode concentration overpotential is zero when oxygen gas is fed, it can be separated by subtracting $\eta_{\text {lf }}$ for oxygen gas from $\eta_{\text {lf }}$ for other oxygen gas partial pressures as presented in Fig. 12(b). This is so-called $\mathrm{O}_{2}$ gain with reference to the case of oxygen gas.
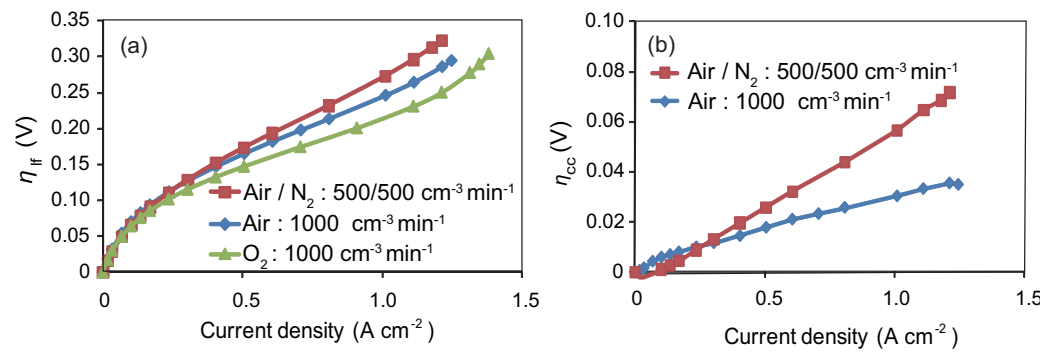

Fig. 12. (a) Overpotential for the low frequency arc and (b) cathode concentration overpotentials of the SOFC for different oxygen partial pressures.

Then the concentration overpotential at the cathode is analyzed in the light of the oxygen transfer at the cathode surface boundary layer. The author calculates the concentration overpotentials from the convective mass transfer using the Sherwood numbers for forced and natural convections for the cells having two different diameters in the cylindrical quartz tube. Then the calculated overpotential is compared with that derived from the EIS measurements. In analogy with the Nusselt number, $N u$, for the circular-tube annulus (Kays \& Perkins, 1985), the Sherwood number, $S h$, is

$$
S h=\frac{h_{\mathrm{O}_{2}} D_{\mathrm{e}}}{D_{\mathrm{O}_{2}}}
$$

where $h_{\mathrm{O}_{2}}$ and $D_{\mathrm{O}_{2}}$ represent the mass transfer coefficient and the binary molecular diffusivity of $\mathrm{O}_{2}$, respectively. $D_{\mathrm{O}_{2}}$ can be calculated from reported values at low temperatures on the basis of the Chapman-Enskog model (Bird et al., 2007). $D_{\mathrm{e}}$ is the hydraulic diameter, $D_{\mathrm{o}}-D_{\mathrm{i}}$, difference between the outer and inner diameters of the circular-tube annulus. In the present case, $D_{\mathrm{o}}$ and $D_{\mathrm{i}}$ are the diameters of the quartz tube and the cell, respectively.

In the case of forced convection, known $N u$ for fully developed laminar flow (Kays \& Perkins, 1985) is used as Sh. 
In the case of natural convection with laminar flow, in analogy with $\mathrm{Nu}$ for vertical fluid layer (Churchill, 1983),

$$
S h=\frac{h_{\mathrm{O}_{2}}\left(r_{\mathrm{o}}-r_{\mathrm{i}}\right)}{D_{\mathrm{O}_{2}}}=0.28 R a^{1 / 4}\left(\frac{l}{r_{\mathrm{O}}-r_{\mathrm{i}}}\right)^{-1 / 4}
$$

where

$$
\begin{aligned}
R a & =G r S c \\
& =\frac{g\left(\rho^{*}-\rho^{\mathrm{el}}\right)\left(r_{\mathrm{o}}-r_{\mathrm{i}}\right)^{3}}{\rho^{*} v D_{\mathrm{O}_{2}}}
\end{aligned}
$$

$l$ is the cathode axial length. $\rho^{*}$ and $\rho^{\mathrm{el}}$ are the densities of the fed and cathode surface gas, respectively, $r_{\mathrm{O}}$ and $r_{\mathrm{i}}$ are the radii of the quartz tube and the cell, respectively. $v$ is the kinematic viscosity of air. In the present chapter, $h_{\mathrm{O}_{2}}$ at $\rho^{\text {el }}$ of fed nitrogen density is used for simplification.

Oxygen flux, $J_{\mathrm{O}_{2}}$ is expressed as

$$
J_{\mathrm{O}_{2}}=h_{\mathrm{O}_{2}}\left(C_{\mathrm{O}_{2}}^{\mathrm{b}}-C_{\mathrm{O}_{2}}^{\mathrm{el}}\right)
$$

where $\mathrm{C}^{\mathrm{b}}$ and $\mathrm{C}_{\mathrm{O}_{2}}^{\mathrm{el}}$ are oxygen concentrations in the fed gas and at the cathode surface, respectively. In the case of natural convection, the mass transfer coefficient is compensated with the average radius, $r_{\mathrm{m}}$, by multiplying $r_{\mathrm{m}} / r_{\mathrm{i}}=\left(r_{\mathrm{o}}-r_{\mathrm{i}}\right) / r_{\mathrm{i}} \ln \left(r_{\mathrm{o}} / r_{\mathrm{i}}\right)$ (Churchill, 1983) to correlate the current density. Since $J_{\mathrm{O}_{2}}$ can be calculated from current, and $h_{\mathrm{O}_{2}}$ and $C_{\mathrm{O}_{2}}^{\mathrm{b}}$ are known, $\mathrm{C}_{\mathrm{O}_{2}}^{\mathrm{el}}$ is yielded.

The cathode concentration overpotential, $\eta_{\mathrm{cc}}$, is given by substituting $C_{\mathrm{O}_{2}}^{\mathrm{el}}$ into the following equation.

$$
\eta_{\mathrm{cc}}=\frac{R T}{\alpha n F}\left(\ln \frac{C_{\mathrm{O}_{2}}^{\mathrm{b}}}{C_{\mathrm{O}_{2}}^{\mathrm{el}}}-\ln \frac{C_{\mathrm{O}_{2}}^{* \mathrm{~b}}}{C_{\mathrm{O}_{2}}^{* \mathrm{el}}}\right)
$$

Here, $\eta_{\mathrm{cc}}$ is derived as the $\mathrm{O}_{2}$ gain with the second term in the right-hand side for $\mathrm{O}_{2}$ gas having negligibly small value.

As presented in Fig. 13, the concentration overpotentials measured from EIS are larger than that calculated for forced convection and smaller than that for natural convection. Despite that $h_{\mathrm{O}_{2}}$ for natural convection is overestimated for simplification, the concentration overpotentials measured are smaller than those for natural convection. The cathode concentration overpotentials in the present experimental set-up are thus determined by the mass transfer in the transition region between forced and natural convections.

Figure 14 shows the measured and calculated cathode concentration overpotentials for the cell having twice the diameter (Ishihara et al., 2009; Watanabe et al., 2010). The concentration overpotential is larger as predicted from the Sherwood numbers of Eq. 3. The concentration overpotentials measured from the EIS are also between those calculated for forced and natural convections.

In this way, the cathode concentration overpotential can be related with the Sherwood number. This is useful for actual SOFC systems because the Sherwood number can be determined for the structure of a cell, alignment of the cells in a stack, and gas feed conditions in the actual systems. 

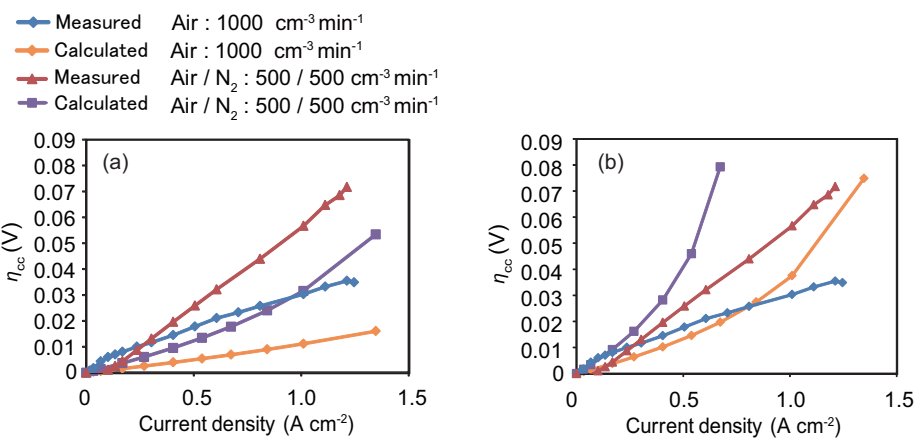

Fig. 13. Comparison of the cathode concentration overpotentials between those from EIS and those calculated for (a) forced convection and (b) natural convection.
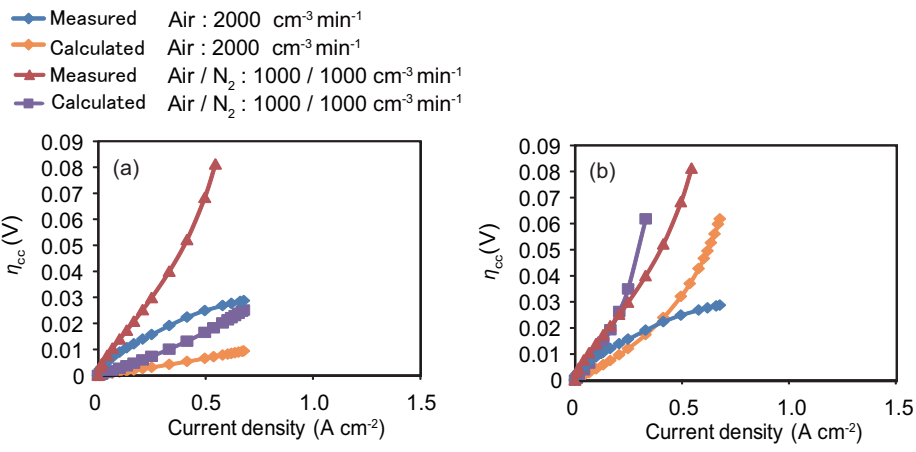

Fig. 14. Comparison of the cathode concentration overpotentials for the cell with twice the diameter between those from EIS and those calculated for (a) forced convection and (b) natural convection.

\subsection{Current distribution in the cell derived from surface temperature measurements}

In this section, current distribution in the axial direction of the cell by the fuel consumption is estimated by comparing the measured and calculated cell surface temperatures on the basis of the derivation of the relation between current (heat production rate) and cell temperature. This relation is derived using the anode, Ohmic, and cathode overpotentials evaluated in the previous section.

\subsubsection{Heat production rates at the anode and cathode}

Rates of irreversible heat production ascribed to the overpotentials are calculated by the product of the overpotentials and current as follows.

$$
q_{\mathrm{op}, \mathrm{x}}=I \eta_{\mathrm{x}}
$$

The author regards the heat production associated with the Ohmic overpotential as that originating in the electrolyte.

Figure 15(a) presents the irreversible heat production rates at the respective parts of the cell calculated from the overpotentials. 



Fig. 15. Heat production rates of the SOFC with (a) the overpotentials, (b) the single electrode Peltier heats, and (c) the sum of them. $\mathrm{H}_{2} / \mathrm{N}_{2}=40 / 40 \mathrm{~cm}^{-3} \mathrm{~min}^{-1}$. Cathode: Dried air of $1000 \mathrm{~cm}^{-3} \mathrm{~min}^{-1}$. $U_{\mathrm{f}}=57 \%$ and $U_{\mathrm{ox}}=5.7 \%$ at $3.0 \mathrm{~A}$.

Reversible heat production with the entropy received reversibly by the anode, the electrochemical Peltier heat at the anode, is then derived from the entropy balance at the anode. The entropy balance for the anode reaction

$$
\frac{1}{2} \mathrm{H}_{2}+\mathrm{O}^{2-} \rightarrow \frac{1}{2} \mathrm{H}_{2} \mathrm{O}+\mathrm{e}^{-}
$$

is expressed as follows on the basis of the local equilibrium hypothesis(Kjelstrup \& Bedeaux, 1997; Nakajima et al., 2004).

$$
\frac{\pi_{\mathrm{a}}}{T}+\frac{1}{2} S_{\mathrm{O}^{2-}}+\frac{1}{2} S_{\mathrm{H}_{2}}=S_{\mathrm{H}_{2} \mathrm{O}}
$$

where $\pi_{\mathrm{a}} / T$ and $S_{\mathrm{O}^{2-}}$ denote the entropies reversibly received by the anode and transported by $\mathrm{O}^{2-}$ in the electrolyte, respectively. $\pi_{\mathrm{a}}$ corresponds to the single electrode Peltier heat. $S_{\mathrm{H}_{2}}$, $S_{\mathrm{H}_{2} \mathrm{O}}$ are the entropies consumed by the formations of $\mathrm{H}_{2}$ and $\mathrm{H}_{2} \mathrm{O}$, respectively.

Here the entropy transported by electrons at the electrode is neglected since its value in metal is negligibly small compared with the other terms in general (Moore \& Graves, 1973; Vedernikov, 1969). In this section, $T$ and $F$ have their common meanings. Because $S_{\mathrm{O}^{2-}}$ in the LSGM has not been reported, that in $\left(\mathrm{ZrO}_{2}\right)_{0.92}\left(\mathrm{Y}_{2} \mathrm{O}_{3}\right)_{0.08}(\mathrm{YSZ})$ obtained by thermoelectric power measurement (Ahlgren \& Willy Poulsen, 1994) is applied.

Then $S_{\mathrm{H}_{2}}$ and $S_{\mathrm{H}_{2} \mathrm{O}}$ are obtained from those at $1 \mathrm{~atm}$ in thermodynamic data. Here, partial pressures of $\mathrm{H}_{2}$ and $\mathrm{H}_{2} \mathrm{O}$ are calculated from the ratio of molar flow rate of the product water 
to that of fed gases. For this calculation, 50 - $75 \%$ of total current is assumed between the inlet and midpoint of the anode tube according to hydrogen utilization to estimate the amounts of the product water and remaining hydrogen at the midpoint, considering current distribution along the axial direction owing to the Nernst loss. Strictly speaking, this partial pressure terms should be excluded for the calculation of total heat production since those terms are included in the measured overpotential as the Nernst loss.

The entropy received by the cathode is also derived from the entropy balance between the formation of $\mathrm{O}_{2}$ and transport of $\mathrm{O}^{2-}$.

$$
\frac{\pi_{\mathrm{c}}}{T}+\frac{1}{2} S_{\mathrm{O}^{2-}}+\frac{1}{2} S_{\mathrm{H}_{2}}=S_{\mathrm{H}_{2} \mathrm{O}}
$$

The relation between current and reversible heat production rates of the anode and cathode are given from the product of the Peltier heats and current as presented in Fig. 15(b).

Since the total heat production rates at the anode, $q_{\mathrm{a}}$, and cathode, $q_{\mathrm{c}}$, are expressed as the sum of the heat production rates associated with the overpotentials and the single electrode Peltier heats as follows,

$$
\begin{aligned}
& q_{\mathrm{a}}=q_{\mathrm{op}, \mathrm{a}}-\frac{I \pi_{\mathrm{a}}}{F} \\
& q_{\mathrm{c}}=q_{\mathrm{op}, \mathrm{c}}+\frac{I \pi_{\mathrm{c}}}{F}
\end{aligned}
$$

the total heat production rates at the respective parts of the cell are shown in Fig. 15(c). These heat production rates seem to represent those in the middle part of the cell (Nakajima et al., 2009). The heat production rate at the cathode is significantly large compared with those at the anode and electrolyte. The heat absorption by the single electrode Peltier heat associated with current can be seen at the anode.

By substituting the total heat production rates per unit volume into the heat conduction (energy balance) equations for the constitutive layers and integrating the differential equations with boundary conditions between the layers and at the surfaces, temperatures at the anode and cathode surfaces can be evaluated.

\subsubsection{Relation between the surface temperature and local current}

Assuming uniform heat flux in the axial direction and temperature in the circumferential direction, the energy balance (the heat conduction) equation at steady state of the anode, electrolyte and cathode layers reduces to

$$
0=\frac{1}{r} \frac{d}{d r}\left(\lambda_{\mathrm{x}} r \frac{d T_{\mathrm{x}}(r)}{d r}\right)+\frac{q_{\mathrm{x}}}{V_{\mathrm{x}}}
$$

Here, $r, T, \lambda$, and $V$ are the radial coordinate, temperature, thermal conductivity, and volume of each layer, respectively. The subscripts, $x=a$, el (Ohm), c represent the anode, electrolyte and cathode layers. The radiation heat transfer is also assumed to be negligible owing to metallic cathode current collector layer (Nakajima et al., 2009). Integration of this simplified 
equation yields the relation between the local current density and temperature in the anode and cathode (Nakajima et al., 2009).

The heat fluxes at the boundaries give the following boundary conditions.

$$
\begin{aligned}
& -\lambda_{\mathrm{el}}\left(\frac{d T_{\mathrm{el}}(r)}{d r}\right)_{r=r_{\mathrm{a}-\mathrm{el}}}=-\lambda_{\mathrm{a}}\left(\frac{d T_{\mathrm{a}}(r)}{d r}\right)_{r=r_{\mathrm{a}-\mathrm{el}}} \\
& -\lambda_{\mathrm{el}}\left(\frac{d T_{\mathrm{el}}(r)}{d r}\right)_{r=r_{\mathrm{c}-\mathrm{el}}}=-\lambda_{\mathrm{c}}\left(\frac{d T_{\mathrm{c}}(r)}{d r}\right)_{r=r_{\mathrm{c}-\mathrm{el}}} \\
& -\lambda_{\mathrm{a}}\left(\frac{d T_{\mathrm{a}}(r)}{d r}\right)_{r=r_{\mathrm{a}, \mathrm{s}}}=h_{\mathrm{fu}}\left(T_{\mathrm{fu}}-T_{\mathrm{a}, \mathrm{s}}\right) \\
& -\lambda_{\mathrm{c}}\left(\frac{d T_{\mathrm{c}}(r)}{d r}\right)_{r=r_{\mathrm{c}, \mathrm{s}}}=h_{\mathrm{air}}\left(T_{\mathrm{c}, \mathrm{s}}-T_{\mathrm{air}}\right)
\end{aligned}
$$

where the subscripts, "c,s" and "c-el" represent the cathode surface and cathode-electrolyte boundary, respectively. $h_{\mathrm{fu}}$ and $h_{\mathrm{air}}$ denote the heat transfer coefficients at the anode and cathode surfaces, respectively. $T_{\mathrm{fu}}$ and $T_{\text {air }}$ are temperatures of fed gases in the anode and cathode sides, respectively, which equal to the cell surface temperature at zero current. The thermal conductivities of the anode and cathode layers are effective values obtained from those of gas phase and materials with the common mixture law in porous media.

The above heat transfer coefficients are calculated by the Nusselt numbers for fully developed laminar flow of forced convection in a circular tube annulus (Kays \& Perkins, 1985). The Nusselt numbers on the anode and cathode are 3.66 and 11.3, respectively for the present experimental set-up. Here, the thermal conductivity of the anode gas, $\lambda_{\mathrm{fu}}$, is estimated from a partial-pressure-weighted average of individual thermal conductivities of fed gases and the product water. Thus $\lambda_{\mathrm{fu}}$ varies with current according to the amounts of the product water and remaining hydrogen.

Substituting these heat production rates into Eq. 15, the author derives the relation between the local current density and temperatures at the surfaces of the anode and cathode using thermal conductivities presented in Table 1.

\begin{tabular}{cc}
\hline Materials and gases & $\lambda\left(\mathrm{W} \mathrm{m}^{-1} \mathrm{~K}^{-1}\right)$ \\
\hline Anode (Effective value)(Wang et al., 2009) & 1.4 \\
Electrolyte (Yasuda et al., 2000) & 2.08 \\
Cathode (Effective value)(Campanari \& Iora, 2004) & 2.0 \\
Hydrogen ( $\left.1 \mathrm{~atm}, 700^{\circ} \mathrm{C}\right)($ PROPATH-group, 2008) & 0.438 \\
Nitrogen $\left(1 \mathrm{~atm}, 700^{\circ} \mathrm{C}\right)($ PROPATH-group, 2008) & 0.064 \\
Water vapor $\left(1 \mathrm{~atm}, 700^{\circ} \mathrm{C}\right)($ PROPATH-group, 2008) & 0.094 \\
Air $\left(1 \mathrm{~atm}, 700^{\circ} \mathrm{C}\right)($ PROPATH-group, 2008) & 0.066 \\
\hline
\end{tabular}

Table 1. Thermal conductivities of the materials and gases in the SOFC.

Thereby the current density at each part can be determined so that the surface temperature calculated at each part of the anode and cathode is identical with the measured temperature. 
In the present study, overpotentials are regarded as uniform in the axis direction because the voltage between the upper and lower ends of the cathode was smaller than $50 \mathrm{mV}$.

In the above analysis, the sensitivity of the derived temperatures to the heat transfer coefficient at the anode surface is rather larger than that to the heat transfer coefficient at the cathode surface and the other thermal conductivities. That is, the contributions of hydrogen partial pressure due to the large thermal conductivity and of anode-supported tube design are significant.

\subsubsection{Local current densities}

Figure 16 shows the surface temperatures of the cell measured at anode gas flow rates of $\mathrm{H}_{2} / \mathrm{N}_{2}=40 / 40,40 / 160 \mathrm{~cm}^{-3} \mathrm{~min}^{-1}$ and a cathode flow rate of dried air of $1000 \mathrm{~cm}^{-3} \mathrm{~min}^{-1}$. In this case, the cathode concentration overpotential is not significant. The temperatures increase with an increase in the cell average current density. The increase in the temperature at the lower parts (upstream) of the anode and cathode are largest.


(b)
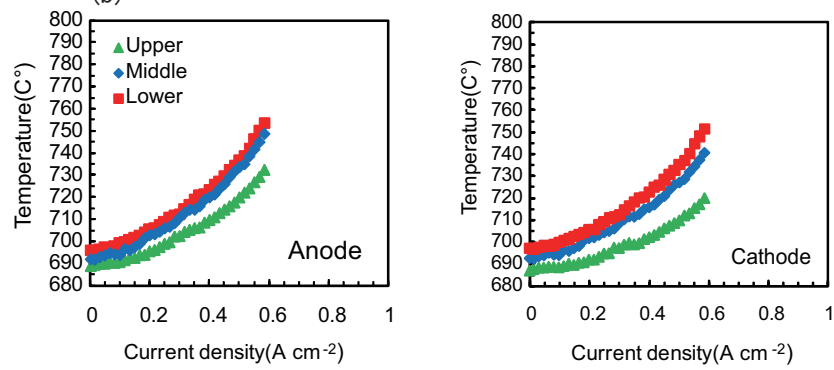

Fig. 16. Surface temperatures against the average current density of the SOFC for (a) $\mathrm{H}_{2} / \mathrm{N}_{2}$ $=40 / 40 \mathrm{~cm}^{-3} \mathrm{~min}^{-1}$ and (b) $\mathrm{H}_{2} / \mathrm{N}_{2}=40 / 160 \mathrm{~cm}^{-3} \mathrm{~min}^{-1}$. Cathode: Dried air of $1000 \mathrm{~cm}^{-3}$ $\min ^{-1}$. $U_{\mathrm{f}}=57 \%$ and $U_{\mathrm{ox}}=5.7 \%$ at $0.5 \mathrm{~A} \mathrm{~cm}^{-2}$.

The temperature distributions represent the current density distributions. With an increase in the cell current, the surface temperature of the anode becomes higher than that of the cathode, especially at the upper part (downstream). This is probably ascribed to the temperature rise of the anode gas from the upstream to the downstream along the axis. Thus the cathode surface temperatures calculated and measured are compared to determine the local current densities at the upper part. In the author's previous report, this anode gas temperature effect was 
overestimated, so that the current densities derived at the upper part were extremely small (Nakajima \& Kitahara, 2011).

The local current densities determined are plotted against the total current in Fig. 17. The current density decreases with the decrease in the hydrogen partial pressure in the fed fuel in accordance with an increase in the average anode activation and concentration overpotentials in the previous section. Hence the current distributions exhibited in the cell are probably ascribed to the hydrogen consumption in upstream. In particular, the current density at the upper part is small in both cases, which shows that the upper part does not effectively take part in the power generation. The higher hydrogen partial pressure results in significantly larger current in the lower part with increasing the temperature and decreasing the overpotentials there. Thus the current distribution is enhanced although the cell power output is increased.

Figure 18 shows the local I-V characteristics. The current distribution seems to be attributed mainly to the concentration overpotential, which also indicates the Nernst loss by the hydrogen consumption in the upstream. The higher temperatures at the lower part also would decrease the Ohmic and activation overpotentials. Total currents calculated by the integration of linearly interpolated local current densities along the axis agree well with the measured current as shown in Fig. 19. Hence the local current densities obtained in the present study are reasonable.
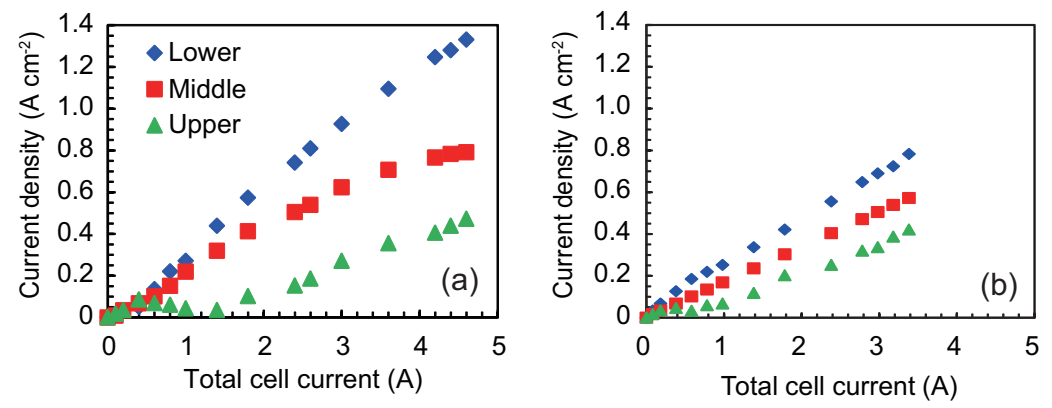

Fig. 17. Local current densities against the total cell current of the SOFC for (a) $\mathrm{H}_{2} / \mathrm{N}_{2}=$ $40 / 40 \mathrm{~cm}^{-3} \mathrm{~min}^{-1}$ and (b) $\mathrm{H}_{2} / \mathrm{N}_{2}=40 / 160 \mathrm{~cm}^{-3} \mathrm{~min}^{-1}$. Cathode: Dried air of $1000 \mathrm{~cm}^{-3}$ $\min ^{-1} \cdot U_{\mathrm{f}}=57 \%$ and $U_{\mathrm{ox}}=5.7 \%$ at $3.0 \mathrm{~A}$.
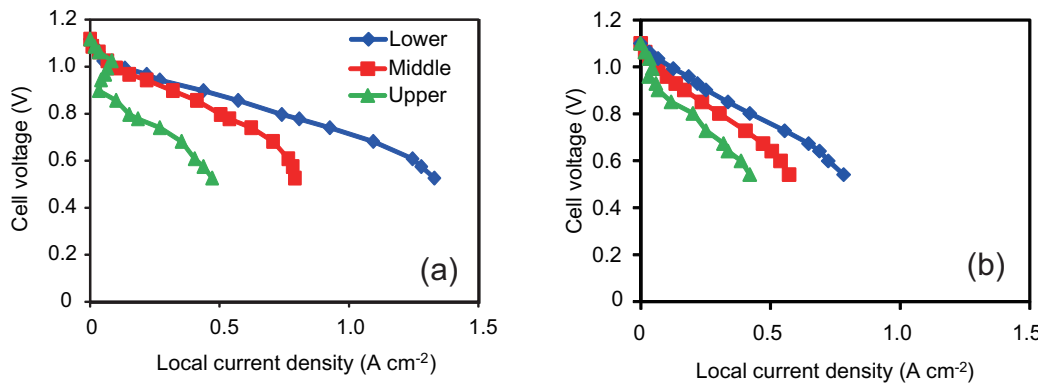

Fig. 18. Local I-V characteristics of the SOFC for (a) $\mathrm{H}_{2} / \mathrm{N}_{2}=40 / 40 \mathrm{~cm}^{-3} \mathrm{~min}^{-1}$ and (b) $\mathrm{H}_{2} / \mathrm{N}_{2}=40 / 160 \mathrm{~cm}^{-3} \mathrm{~min}^{-1}$. Cathode: Dried air of $1000 \mathrm{~cm}^{-3} \mathrm{~min}^{-1}$. 

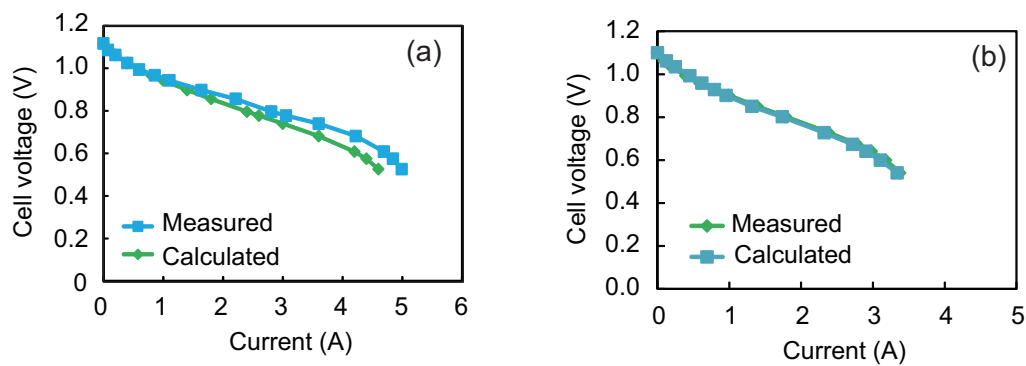

Fig. 19. Comparison of the calculated and measured I-V characteristics of the SOFC for (a) $\mathrm{H}_{2} / \mathrm{N}_{2}=40 / 40 \mathrm{~cm}^{-3} \mathrm{~min}^{-1}$ and (b) $\mathrm{H}_{2} / \mathrm{N}_{2}=40 / 160 \mathrm{~cm}^{-3} \mathrm{~min}^{-1}$. Cathode: Dried air of $1000 \mathrm{~cm}^{-3} \mathrm{~min}^{-1}$.

\section{Conclusion}

In this chapter, EIS analysis clarifies the concentration overpotentials determined by the fuel and oxygen transfers in an intermediate temperature anode-supported microtubular SOFC. Current distribution in the cell by the Nernst loss due to the fuel partial pressure gradient along the axis of the cell is also described from surface temperature measurements. These results give the information for the optimization of the cell structure, cell alignment in the stack and operation conditions to decrease the anode concentration overpotential including the Nernst loss, for effective use of the whole electrodes in the cell, and to improve the durability of the cell by more uniform current and temperature distributions.

\section{Acknowledgments}

This work was supported by a grant of the Fukuoka Strategy Conference for Hydrogen Energy in the Fukuoka prefectural government, Japan. The author is also grateful to graduate students, Satoshi IGAUE, Atsushi OKAZAKI, Ryota MATSUMOTO, and Ken-ichi KIYAMA for assistance with the measurements and calculations.

\section{References}

Ahlgren, E. \& Willy Poulsen, F. (1994). Thermoelectric power of YSZ, Solid State Ionics 70-71(PART 1): 528-532.

Barfod, R., Mogensen, M., Klemensø, T., Hagen, A., Liu, Y. L. \& Hendriksen, P. V. (2007). Detailed characterization of anode-supported SOFCs by impedance spectroscopy, Journal of the Electrochemical Society 154(4): B371-B378.

Barsoukov, E. \& Macdonald, J. R. (eds) (2005). Impedance Spectroscopy: Theory, Experiment, and Applications, 2nd edn, John Wiley \& Sons, New York.

Bird, R. B., Stewart, W. E. \& Lightfoot, E. N. (2007). Transport Phenomenon, 2nd edn, John Wiley \& Sons, New York.

Campanari, S. \& Iora, P. (2004). Definition and sensitivity analysis of a finite volume SOFC model for a tubular cell geometry, Journal of Power Sources 132(1-2): 113-126.

Churchill, S. W. (1983). in E. U. Schlunder (ed.), Heat exchanger design handbook, Hemisphere. 
Costamagna, P. \& Honegger, K. (1998). Modeling of solid oxide heat exchanger integrated stacks and simulation at high fuel utilization, Journal of the Electrochemical Society 145(11): 3995-4007.

Esquirol, A., Brandon, N. P., Kilner, J. A. \& Mogensen, M. (2004). Electrochemical characterization of $\mathrm{La}_{0.6} \mathrm{Sr}_{0.4} \mathrm{Co}_{0.2} \mathrm{Fe}_{0.8} \mathrm{O}_{3}$ cathodes for intermediate- temperature SOFCs, Journal of the Electrochemical Society 151(11): A1847-A1855.

Horita, T., Yamaji, K., Sakai, N., Yokokawa, H., Weber, A. \& Ivers-Tiffée, E. (2001). Oxygen reduction mechanism at porous $\mathrm{La}_{1-x} \mathrm{Sr}_{x} \mathrm{CoO}_{3-d}$ cathodes $/ \mathrm{La}_{0.8} \mathrm{Sr}_{0.2} \mathrm{Ga}_{0.8} \mathrm{Mg}_{0.2} \mathrm{O}_{2.8}$ electrolyte interface for solid oxide fuel cells, Electrochimica Acta 46(12): 1837-1845.

Huang, Q. A., Hui, R., Wang, B. \& Zhang, J. (2007). A review of ac impedance modeling and validation in SOFC diagnosis, Electrochimica Acta 52(28): 8144-8164.

Ishihara, T., Eto, H., Zhong, H. \& Matsumoto, H. (2009). Intermediate temperature solid oxide fuel cells using $\mathrm{LaGaO}_{3}$ based perovskite oxide for electrolyte, Electrochemistry 77(2): 115-122.

Ishihara, T., Shibayama, T., Nishiguchi, H. \& Takita, Y. (2000). Nickel-Gd-doped $\mathrm{CeO}_{2}$ cermet anode for intermediate temperature operating solid oxide fuel cells using $\mathrm{LaGaO}_{3}$-based perovskite electrolyte, Solid State Ionics 132: 209-216.

Jiang, S. P. (2002). A comparison of $\mathrm{O}_{2}$ reduction reactions on porous (La,Sr) $\mathrm{MnO}_{3}$ and $(\mathrm{La}, \mathrm{Sr})(\mathrm{Co}, \mathrm{Fe}) \mathrm{O}_{3}$ electrodes, Solid State Ionics 146(1-2): 1-22.

Kanamura, K. \& Takehara, Z. (1993). Temperature and thermal stress distributions in a tubular solid oxide fuel cell, Bulletin of the Chemical Society of Japan 66(10): 2797-2803.

Kawakami, A., Matsuoka, S., Watanabe, N., Saito, T., Ueno, A., Ishihara, T., Sakai, N. \& Yokokawa, H. (2006). Development of two types of tubular SOFCs at TOTO, Ceram. Eng. Sci. Proc. 27(4)(3): 3-13.

Kays, W. M. \& Perkins, H. C. (1985). Forced convection, internal flow in ducts, in W. M. Rohsenow, J. P. Hartnett \& E. N. Ganic (eds), Handbook of Heat Transfer, 2nd edn, McGraw-Hill, New York.

Kjelstrup, S. \& Bedeaux, D. (1997). Jumps in electric potential and in temperature at the electrode surfaces of the solid oxide fuel cell, Physica A: Statistical Mechanics and its Applications 244(1-4): 213-226.

Konomi, T. \& Saho, I. (2006). Research of diagnosis technique on PEFC running condition (overvoltage analysis and diagnosis of PEFC by FFT), Transactions of the Japan Society of Mechanical Engineers, Series B 72(2): 455-462.

Leonide, A., Rüger, B., Weber, A., Meulenberg, W. A. \& Ivers-Tiffée, E. (2010). Impedance study of alternative (La,Sr) $\mathrm{FeO}_{3-\delta}$ and $(\mathrm{La}, \mathrm{Sr})(\mathrm{Co}, \mathrm{Fe}) \mathrm{O}_{3-\delta}$ MIEC cathode compositions, Journal of the Electrochemical Society 157(2): B234-B239.

$\mathrm{Li}$, X. (2007). Thermodynamic performance of fuel cells and comparison with heat engines, in T. S. Zhao, K.-D. Kreuer \& T. V. Nguyen (eds), Advances in Fuel Cells, Vol. 1, Elsevier, Amsterdam.

McIntosh, S., Vohs, J. M. \& Gorte, R. J. (2003). Impedance spectroscopy for the characterization of Cu-ceria-YSZ anodes for SOFCs, Journal of the Electrochemical Society 150(10): A1305-A1312.

Moore, J. P. \& Graves, R. S. (1973). Absolute seebeck coefficient of platinum from 80 to 340 $\mathrm{K}$ and the thermal and electrical conductivities of lead from 80 to $400 \mathrm{~K}$, Journal of Applied Physics 44(3): 1174-1178. 
Morita, H., Komoda, M., Mugikura, Y., Izaki, Y., Watanabe, T., Masuda, Y. \& Matsuyama, T. (2002). Performance analysis of molten carbonate fuel cell using a Li/Na electrolyte, Journal of Power Sources 112(2): 509-518.

Nakajima, H. \& Kitahara, T. (2011). Current distribution analysis of a microtubular solid oxide fuel cell with surface temperature measurements, ECS Transactions 35(1): 1087-1096.

Nakajima, H., Kitahara, T. \& Konomi, T. (2010). Electrochemical impedance spectroscopy analysis of an anode-supported microtubular solid oxide fuel cell, Journal of the Electrochemical Society 157(11): B1686-B1692.

Nakajima, H., Konomi, T. \& Kitahara, T. (2009). Thermal analysis of a microtubular solid oxide fuel cell using electrochemical impedance spectroscopy, ECS Transactions 25(2): 359-368.

Nakajima, H., Konomi, T., Kitahara, T. \& Tachibana, H. (2008). Electrochemical impedance parameters for the diagnosis of a polymer electrolyte fuel cell poisoned by carbon monoxide in reformed hydrogen fuel, Journal of Fuel Cell Science and Technology 5: 041013.

Nakajima, H., Nohira, T. \& Ito, Y. (2004). The single electrode peltier heats $\mathrm{of}_{\mathrm{Li}}^{+} / \mathrm{Li}$, $\mathrm{H}_{2} / \mathrm{H}^{-}$and $\mathrm{Li}^{+} / \mathrm{Pd}-\mathrm{Li}$ couples in molten $\mathrm{LiCl}-\mathrm{KCl}$ systems, Electrochimica Acta 49(27): 4987-4991.

Nakajima, H., Nohira, T. \& Ito, Y. (2005). Electrochemical impedance spectroscopy study of a hydrogen electrode reaction at a $\mathrm{Zn}$ electrode in a molten $\mathrm{LiCl}-\mathrm{KCl}-\mathrm{LiH}$ system, Journal of Physical Chemistry B 109(19): 9645-9650.

Nakajima, H., Nohira, T., Ito, Y., Kjelstrup, S. \& Bedeaux, D. (2006). The surface adsorption of hydride ions and hydrogen atoms on $\mathrm{Zn}$ studied by electrochemical impedance spectroscopy with a non-equilibrium thermodynamic formulation, Journal of Non-Equilibrium Thermodynamics 31(3): 231-255.

Nishino, T., Iwai, H. \& Suzuki, K. (2006). Comprehensive numerical modeling and analysis of a cell-based indirect internal reforming tubular SOFC, Journal of Fuel Cell Science and Technology 3(1): 33-44.

PROPATH-group (2008). A program package for thermophysical properties of fluids, PROPATH, ver. 13.1 .

URL: http://gibbs.mech.kyushu-u.ac.jp/akasaka/propath_man/

Suzuki, M., Shikazono, N., Fukagata, K. \& Kasagi, N. (2008). Numerical analysis of coupled transport and reaction phenomena in an anode-supported flat-tube solid oxide fuel cell, Journal of Power Sources 180(1): 29-40.

Ueno, A. (2005). Manufacturing and applications of a tubular fuel cell stack fabricated by wet process (in Japanese), in K. Eguchi (ed.), Development of Solid Oxide Fuel Cell, CMC Publishing, Tokyo.

Vedernikov, M. V. (1969). Thermoelectric powers of transition metals at high temperatures, Advan Phys 18(74): 337-369.

Wang, Y., Yoshiba, F., Kawase, M. \& Watanabe, T. (2009). Performance and effective kinetic models of methane steam reforming over Ni/YSZ anode of planar SOFC, International Journal of Hydrogen Energy 34(9): 3885-3893.

Watanabe, N., Kawakami, A., Oe, T. \& Ishihara, T. (2010). Research of current collect property in micro tubular solid oxide fuel cell (1st report, evaluation of current collecting of single terminal in anode), Transactions of the Japan Society of Mechanical Engineers, Series B 76(768): 1224-1231. 
Yasuda, I., Matsuzaki, Y., Yamakawa, T. \& Koyama, T. (2000). Electrical conductivity and mechanical properties of alumina-dispersed doped lanthanum gallates, Solid State Ionics 135(1-4): 381-388. 


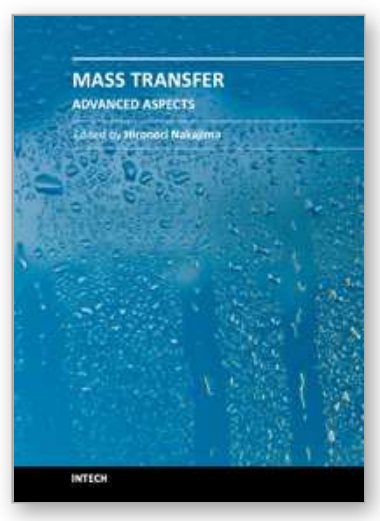

\author{
Mass Transfer - Advanced Aspects \\ Edited by Dr. Hironori Nakajima
}

ISBN 978-953-307-636-2

Hard cover, 824 pages

Publisher InTech

Published online 07, July, 2011

Published in print edition July, 2011

Our knowledge of mass transfer processes has been extended and applied to various fields of science and engineering including industrial and manufacturing processes in recent years. Since mass transfer is a primordial phenomenon, it plays a key role in the scientific researches and fields of mechanical, energy, environmental, materials, bio, and chemical engineering. In this book, energetic authors provide present advances in scientific findings and technologies, and develop new theoretical models concerning mass transfer. This book brings valuable references for researchers and engineers working in the variety of mass transfer sciences and related fields. Since the constitutive topics cover the advances in broad research areas, the topics will be mutually stimulus and informative to the researchers and engineers in different areas.

\title{
How to reference
}

In order to correctly reference this scholarly work, feel free to copy and paste the following:

Hironori Nakajima (2011). Electrochemical Impedance Spectroscopy Study of the Mass Transfer in an AnodeSupported Microtubular Solid Oxide Fuel Cell, Mass Transfer - Advanced Aspects, Dr. Hironori Nakajima (Ed.), ISBN: 978-953-307-636-2, InTech, Available from: http://www.intechopen.com/books/mass-transfer-advancedaspects/electrochemical-impedance-spectroscopy-study-of-the-mass-transfer-in-an-anode-supportedmicrotubular

\section{INTECH}

open science | open minds

\author{
InTech Europe \\ University Campus STeP Ri \\ Slavka Krautzeka 83/A \\ 51000 Rijeka, Croatia \\ Phone: +385 (51) 770447 \\ Fax: +385 (51) 686166 \\ www.intechopen.com
}

\author{
InTech China \\ Unit 405, Office Block, Hotel Equatorial Shanghai \\ No.65, Yan An Road (West), Shanghai, 200040, China \\ 中国上海市延安西路65号上海国际贵都大饭店办公楼405单元 \\ Phone: +86-21-62489820 \\ Fax: +86-21-62489821
}


(C) 2011 The Author(s). Licensee IntechOpen. This is an open access article distributed under the terms of the Creative Commons Attribution 3.0 License, which permits unrestricted use, distribution, and reproduction in any medium, provided the original work is properly cited. 